\title{
Hormonal control of protein deposition in animals
}

By Peter J. Buttery, Department of Applied Biochemistry and Food Science, University of Nottingham School of Agriculture, Sutton Bonington, Near Loughborough, Leics. LE $12{ }_{5} R D$

The hormonal control of protein deposition in animals is a highly integrated process. Consideration of this topic not only requires a study of hormonal interactions with target tissues but also the much more general topic of growth. Growth itself is a complex and integrated process and involves the formation and enlargement of many metabolic units. Obviously maximal protein deposition in an animal only occurs when the overall status of the animal favours anabolism. In this review the production of protein for export from the tissues, e.g. hair, milk and eggs, will not be considered. The production of milk and egg protein is subject to considerable hormonal control and will be considered elsewhere in this Symposium. As pointed out by Young ( 1980 ) protein metabolism is intimately affected by, and related to, the status of carbohydrate and lipid metabolism in the whole organism and these aspects of metabolism are also subject to considerable hormonal control. A detailed evaluation of the many reports of the effects of a wide variety of hormones on the many facets of protein metabolism is not possible in the space available but instead an attempt will be made to consider those aspects which are relevant to the manipulation of the hormonal status of animals. No attempt will be made to present a catalogue of the effects of various hormones and hormone-like substances on growth and carcass composition, this has recently been reviewed by Galbraith \& Topps (1981); nor will any attempt be made to review in detail the neuro-endocrinological control of hormone secretion, an area in which considerable advances are to be expected during the next decade.

\section{Growth hormone}

The main action of growth hormone (GH) on protein metabolism is anabolic. Raben (1973) concluded that the primary role of $\mathrm{GH}$ was to preserve protein reserves, particularly during periods of energy deficiency, by stimulating the incorporation of amino acids into protein whilst diverting glucose away from tissue deposition. Muscle protein synthesis is clearly stimulated (e.g. Kostyo \& Nutting, 1973). Although plasma GH concentrations are not closely correlated to total body growth rate of cattle, the daily average secretion of $\mathrm{GH}$ has been positively correlated with growth of carcass lean tissue and negatively correlated with carcass adipose tissue (Trenkle, 1977; Trenkle \& Topel, 1978). This is consistent with the lipolytic and proteogenic activities of this hormone. Treatment of other animals with GH shows similar trends, for example, lambs (Wagner \& Veenhuizen, 1978) and pigs (Machlin, 1972). 
GH extracted from pituitaries has been shown to be heterogenic and the different entities may have different in vivo effects (Lewis et al. 1980; Hart, 1981). These observations may go a long way towards providing an explanation for a large number of quite different biological effects ascribed to GH. The secretion of $\mathrm{GH}$ from the pituitary is inhibited by somatostatin and immunization of animals against somatostatin has promoted increased growth rates (Spencer, I981a). However, somatostatin appears to have a wide range of effects; for example, the inhibition of thyroid-stimulating-hormone, stimulation of the secretion of the thyroid hormones, inhibition of secretion of insulin, glucagon and gastrointestinal hormones (Patel et al. I98I). The action of GH is closely associated with the somatomedins. The chemistry and biological activity of these substances, together with considerations of their influence on growth have been the subjects of several books and reviews (e.g. Giordino et al. 1979; Spencer, 1981 b). The relationship between these substances and insulin action is also an area of great interest (see Spencer, $1981 \mathrm{I} a$ ). The effects of $\mathrm{GH}$ on muscle protein synthesis may be due to the direct production of somatomedin in muscle following GH stimulation (Spencer, 1981). There have been few direct studies on somatomedins and growth in farm animals but generally there is evidence for a positive relationship between plasma somatomedin concentration and growth rate (e.g. Gregory et al. 1977; Lund-Larsen et al. 1977). This is, however, not universally true. For example, in children being treated with methyl-testosterone, growth rate was inversely related to somatomedin concentration (Van den Brande et al. 1979). Ashton (1981) lists several other cases where circulating somatomedin concentration does not reflect circulatory GH concentration. The difficulty of working with somatomedins is largely associated with assay problems. Although there are several bioassay methods (e.g. Coates et al. 1977) they tend to be influenced by other factors in the serum. The development of specific radioimmunoassays and receptor assays should help to clarify the situation but the presence in plasma of numerous biologically active peptides still leaves plenty of room for confusion. Perhaps one of the most exciting developments in endocrinology over the last few years has been the investigations on the influence of neurally active peptides on circulating hormone concentrations (see Schofield, $198 \mathrm{r}$ ). This interesting observation has led to the design of a number of peptides which are highly active and selective stimuli for in vitro and in vivo GH release (Momany et al. 1981). The use of these substances may be a way of indirectly promoting growth of animals by enhancing GH production.

\section{Corticosteroids}

Cortisol and corticosterone have catabolic effects on protein metabolism in muscle and it might be expected that high circulating concentrations would be associated with slower growth rates. Following studies with cattle this has been demonstrated on several occasions (e.g. Purchas et al. 1971; Trenkle \& Topel, r 978) but there are reports that do not confirm this (e.g. Lange \& Lindermann, 1972). Purchas et al. (1980) obtained a much more pronounced negative 
correlation between growth rate and circulating corticosteroid concentration in cattle than they did with sheep. A most surprising observation was that on at least one occasion administration of corticosteroids has resulted in increased growth rates (Purchas, 1973). The main effect of cortisone injection, at least in cattle, is to increase the fat content of the carcass while reducing the protein content, an observation consistent with the lipogenic action of this hormone (see Carroll et al. 1963).

Studies on the rat have indicated quite clearly that corticosteroids suppress protein synthesis in muscle (Shoji \& Pennington, 1977; Rannels et al. 1978). There is apparent controversy over the effects of this hormone on protein degradation. At least as judged by $\mathrm{N}^{\mathrm{t}}$-methyl histidine excretion following subcutaneous injection, there is a marked increase in muscle protein (or to be more accurate, total body actin degradation) (Tomas et al. 1979). Other workers have not confirmed this observation (Millward et al. 1976; Shoji \& Pennington, 1977) but they used an intraperitoneal injection. Santidrian et al. (1981) have shown that these differences were probably a result of the different routes of administration. In a later paper, Odedra \& Millward (1982) obtained little evidence for an increase in muscle protein degradation on corticosterone treatment, although some of their other results on $\mathrm{N}^{\mathrm{t}}$-methyl histidine concentrations in muscle may not be entirely consistent with this. One of the most interesting findings from the type of studies outlined above, using adrenalectomized and intact animals given relatively large doses of glucocorticoids, is the interrelationships between plasma corticosterone and insulin concentrations. Presumably this insulin is 'attempting' to counteract the catabolic effects of the glucocorticoids (Odedra \& Millward, 1982). In diabetic rats, administration of insulin does not stimulate protein synthesis in muscle unless the animal is adrenalectomized; diabetic rats have higher corticosterone concentrations than controls (Odedra et al. 1982). It is also interesting to note that while insulin promotes the uptake of amino acids into muscle, cortisol promotes an increased efflux of amino acids from muscle (Rannels \& Jefferson, I980; Lewis \& Goldspink, 1982). In diabetic rats maintained with a continuous infusion of insulin, the magnitude of the decrease in fractional synthetic rate of skeletal muscle following corticosterone concentration was dependent upon the type of muscle. The oxidative soleus muscle appeared to be less susceptible than the more glycolytic plantaris or gastrocnemius muscle (Odedra \& Millward, I982). Rannels \& Jefferson (1980) have also noted similar differences in the response to glucocorticoids by glycolytic and oxidative muscles. These observations, together with the different effects of thyroid hormones on skeletal muscle and heart (see below), clearly indicate the danger in assuming all muscle responds identically to the influence of hormones.

These studies, all with acute changes in corticosterone status, do suggest that concentrations of corticosterone should be universally related to growth rate. Although this area might be explored to promote growth, it has to be conceeded that growth is normally being held back by physiological concentrations of corticosterone. Van den Brande et al. (1979) have suggested that physiological 
concentrations of corticosteroids may retard the growth of children receiving steroids for treatment of renal failure. Studies on the growth rate of adrenalectomized animals are relatively unhelpful as removal of the adrenals affects things other than glucocorticoid production.

\section{Insulin}

Insulin is anabolic, at least as far as protein metabolism is concerned. It stimulates amino acid transport, protein, RNA and DNA synthesis. The hormone, however, has many other effects on metabolism. It is most interesting to note that responses to insulin have different dose-response curves, e.g. $10^{-11} \mathrm{M}$ for its antilipogenic effect and $10^{-7} \mathrm{M}$ for its growth-promoting effect (DNA synthesis). The time taken for these responses also varies (Kahn et al. I98I). The growth-promoting effects of insulin (e.g. stimulation of DNA synthesis) may be mediated by pathways quite distinct from its effects on carbohydrate metabolism. As with many hormones, the affinity and concentration of the receptors for insulin are regulated by many factors in health and disease, e.g. obesity, non-insulin dependent diabetes, states of $\mathrm{GH}$ and states of glucocorticoid excess and deficiency (Kahn et al. 1981). A major regulating factor is the concentration of insulin itself as receptor concentration is inversely related to insulin concentration, a phenomenon known as 'down regulation' (Livingston et al. 1978).

As discussed above, diabetic rats have reduced rates of muscle protein synthesis and an elevated plasma corticosterone concentration. There is evidence that this elevated corticosterone concentration inhibits the effects of exogenously applied insulin on muscle protein synthesis (Odedra \& Millward, 1982; Odedra et al. I982). This is another example of a possible interrelationship between hormones, although in this case it would be more interesting if the relationship could be demonstrated in 'normal' animals.

A group of factors termed insulin-like growth factors, e.g. IGF1, IGF2, somatomedin A, somatomedin C, multiplication stimulating activity (MSA), have attracted much attention recently and their relationship with insulin itself has been reviewed by Kahn et al. (1981), where the relationship between the receptors for insulin and those for IGFs is discussed. The binding of MSA to adipocytes can be stimulated by insulin, another example of an interaction of hormones.

In sheep it has been suggested that insulin stimulates the uptake of amino acids by the peripheral tissues rather than the liver (Brockman et al. 1975) and, by using the perfused ruminant diaphragm (Coward \& Buttery, 1980), we have been able to demonstrate a stimulation of protein synthesis in ruminant muscle (Shepperson and Buttery, unpublished observations).

The effects of insulin status on protein deposition in the carcass is not clear. In pigs, insulin infusion increased nitrogen retention over and above that seen with glucose infusion (Fuller et al. 1977) but these observations have not been confirmed in sheep (Sumner \& Weekes, 1983 ). When considering ruminants, the effects of hormones on the rumen and its function should not be ignored. Insulin has been shown to stimulate rumen epithelium mitosis (Sakata et al. 1980) and 
there is also evidence to suggest that prolactin may increase the outfiow of particulate materials from the rumen (Stephenson et al. $198_{3}$ ).

\section{Androgens}

Testosterone tends to be anabolic and stimulates muscle protein synthesis (Kochakin, 1975). Castrated animals of many species tend to grow at a slower rate than entire animals. Ram lambs immunized against testosterone grow at the same rate as castrated animals, both being slower than control rams (Schanbacker, 1982). Administration of testosterone to steers has been reported to increase muscle mass (Burgess \& Lamming, 1 960 ) and growth rate of female rats (Vernon \& Buttery, 1978a). However, Rodway \& Galbraith (1979) were unable to stimulate growth in female rats with testosterone. The rate of protein synthesis in male rats is faster than that in females (Waterlow \& Stephen, I968).

It has been suggested that androgens might exert their influence on muscle metabolism by inhibiting the binding of the glucocorticoids with their muscle receptor, thereby depressing the catabolic effects of glucocorticoids (Mayer \& Rosen, 1975). In recent studies, however, this suggestion has not been confirmed. In both rat and porcine muscle, distinct glucocorticoid and androgenic receptors have been found and there appears to be little evidence of cross binding (Snochowski et al. 1980, 1981).

Although the influence of androgens on the growth of muscle is most likely to be mediated via hormone-specific receptors which react with DNA (see Young, I980), it cannot be excluded that androgens may act on muscle following aromatization to oestrogens (MacDonald et al. 1979; Anderson \& Lieberman, 1980). It has been suggested that muscle may be responsible for $25-30 \%$ of the peripheral oestrogen production from androgens (Longcope et al. 1978).

\section{Oestrogens}

In ruminants, treatment with oestrogens tends to promote an increase in body-weight in direct contrast to man and the rat, where they tend to be catabolic. In the rat it has been suggested that much of the effect of oestrogens on growth is due to a suppression of appetite (see Galbraith \& Topps, 198I). In mice, small doses of diethylstilbestrol have been reported to increase $\mathrm{N}$ retention but larger doses were found to be catabolic (Wilbur et al. 1967).

Oestrogens are said to exert their influence on growth by the secondary action of other hormones, e.g. an increase in $\mathrm{GH}$ or a change in the thyroid-hormone status of the animal (Heitzman, 1981). It has been suggested that a direct action on muscle metabolism by oestrogenic compounds is unlikely (Heitzman, 1981). However, strong evidence for the presence of oestradiol receptors in muscle has recently been obtained. Dahlberg ( 1982 ) investigated the equilibrium dissociation constant of a rat skeletal muscle oestrogen receptor and showed that the receptor interacted with DNA covalently coupled to agarose. He was also able to purify the receptor some twenty-five-fold. On examination of a wide variety of steroids for competitive binding with 17- $\alpha$-ethynyl-1 $\beta$-methoxyestradiol-17 $\beta$ (a synthetic 
oestrogenic compound used in many of his studies) he concluded that the muscle oestrogen receptor had similar properties to the oestrogen receptor in tissues which are thought of as classical oestrogen targets. The number of sites in muscle is affected by the sexual status of the animal (Dionne et al. 1979). Recent studies in this laboratory have yielded strong indications that sheep skeletal muscle also contains a receptor for oestradiol (P. A. Sinnett-Smith, C. A. Palmer and P. J. Buttery, unpublished observations) but whether oestrogens have any significant direct effects on muscle metabolism in vivo still remains to be shown.

\section{Thyroid hormones}

Hyperthyroidism is associated with a decreased skeletal mass. In rats, at least, experimental hyperthyroidism is associated with an increased skeletal muscle lysosomal proteinase activity (De Martino \& Goldberg, 1978) and increased $\mathrm{N}^{\mathrm{t}}$-methyl histidine excretion (Carter et al. 1981). Muscle-protein degradation falls following thyroidectomy and is restored on $3,5,3^{\prime}$-triiodothyronine $\left(\mathrm{T}_{3}\right)$ treatment (Brown et al. 198I). It has been suggested that the fall in degradation during protein deficiency may result from reduced $T_{3}$ concentrations (Cox et al. 198I). Reduction in the availability of $\mathrm{T}_{3}$ also reduces muscle fractional synthetic rate (Brown et al. I98I). The response to thyroid hormones is, however, very dose dependent. While restoration of thyroid status returns protein synthesis and degradation to normal, further increases in the availability of thyroid hormones result in an even more extensive muscle protein catabolism uncompensated by increased protein synthesis (Goldberg et al. 1980).

Recent work following the measurement of fractional rates of skeletal muscle protein synthesis and changes in muscle mass have confirmed that hyperthyroidism is associated with an increased rate of protein breakdown. There is also an increase in the rate of skeletal muscle protein synthesis during experimental hyperthyroidism (Carter et al. 1982) but this was less than the increase in proteolysis, hence the reduction in skeletal mass. In the heart, again an increase in synthetic rate of protein was observed but there was no significant change in protein breakdown. Hyperthyroidism is associated with cardiac hypertrophy (Beznak, 1982 ).

The results of Carter et al. (1982) were not identical to those of Flaim et al. (1979) who were unable to show increased skeletal muscle proteolysis and protein synthesis. What is clear is that there is considerable evidence to suggest that at physiological concentrations, thyroid hormones have an important role to play in the control of muscle protein deposition. It is interesting to note that some of the early growth promoters were thyrostatic agents (Burroughs et al. 1958).

\section{Gastrointestinal hormones}

There is a wide range of hormones produced by the gastrointestinal tract and it is attractive to implicate these hormones with the changes in plasma hormone concentrations seen on variation of the diet. The effects of level of intake on metabolic activity of anabolic and catabolic hormones have been discussed by 
Weekes \& Godden (1981) who came to the conclusion that, while it would be expected that intake should be positively correlated to anabolic hormone activity, and negatively correlated to catabolic hormone activity, there are surprisingly few statistically significant observations to support this hypothesis. As discussed by Weekes \& Godden (1981), there are also examples of diet composition affecting hormonal activity, even in ruminants where rumen fermentation tends to even out the composition of the diet reaching the intestines. Berzins \& Manns (1979) demonstrated that plasma gut-type glucagon (glucagon-like immuno reactivity) is elevated when steers are given increasing amounts of grain. Manns (1972) has also shown that this hormone increases in dairy cows following parturition, a time when more concentrates are fed. It is possible that this hormone binds to hepatic glucagon receptors and thereby makes the animal more susceptible to ketosis in lactation. The effect, directly or indirectly on protein deposition, of gastrointestinal hormone secretion and action is difficult to assess but it is a most interesting area and the reader is referred to Patel et al. (1981).

\section{Action of synthetic hormone-like substances designed to promote protein deposition}

Several synthetic compounds have been used to promote growth and in many cases increase the protein content of the carcass (see Heitzman, 198I). Classically, androgenic compounds would be expected to increase protein synthesis and hence protein deposition in muscle. Indeed this would appear to be the response to Durabolin ${ }^{\circledR}$ (nandrolone phenylpropionate), at least in the rat (Table 1 ). It is relatively easy to accept that part, at least, of this response is due to a direct action of the compound on skeletal muscle. Not all compounds that are apparently androgenic promote synthesis in muscle. For example, trenbolone decreases protein synthesis and protein degradation in muscle (see Table I). As discussed above, many hormones affect muscle metabolism, e.g. GH, somatomedins, insulin and the thyroid hormones. It is, therefore, possible that trenbolone may act by altering the activity of one or more of these hormones. Indeed small changes have been reported in the activity of some of these hormones, e.g. a decrease in thyroxine $\left(T_{4}\right)$ and free $T_{3}$ in cattle and sheep (Donaldson et al. $198 \mathrm{r}$ ). This observation has, however, not been seen in the rat (N. W. Dumelow, A. N. Brooks and P. J. Buttery, unpublished observations) where trenbolone has similar effects on protein metabolism in muscle as those seen in the sheep (see Tables $I$ and 3 ). Trenbolone binds to a variety of receptors (Table 2) and it may be that it is acting via its influence on one of these receptors. Circumstantial evidence does implicate a reduction of corticosterone/cortisol action as a possible mode of action of trenbolone (reduced circulating glucocorticoid concentrations have been reported in treated animals (Thomas \& Rodway, 198I) and tyrosine transaminase (EC 2.6.1.5) activities were reduced in the livers of treated rats (Rodway \& Galbraith, 1979)). While it is unlikely that trenbolone directly competes with the muscle glucocorticoid receptor, as was originally proposed by Buttery et al. (1978), it is possible that the agent inhibits the production of glucocorticoids by the adrenals (Thomas \& Rodway, 1983). This response is not, however, specific for trenbolone. 
Table 1. The effect of Durabolin ${ }^{\mathbb{R}}$ and trenbolone on the metabolism of the female rat

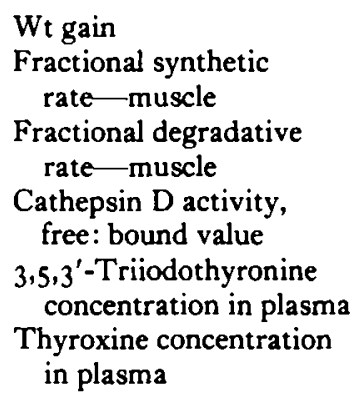

Also, it should be remembered that the effects of glucocorticoids on muscle protein deposition are apparently on synthesis, rather than degradation (see previously). Trenbolone would appear to have a more marked effect on muscle protein degradation than on muscle protein synthesis. It would be enlightening to see if the effects of trenbolone on glucocorticoids are seen under conditions where trenbolone promotes little growth response, e.g. in the male rat.

When considering the control of protein deposition by hormones, the relationship between the hypothalamus and the anterior pituitary gland must be explored. Some interesting experiments describing the effects of trenbolone on androgenized rats have been reported by Toong et al. (1981). These workers observed that the growth of androgenized females did not respond to trenbolone. In contrast, ovectomized and luteinizing hormone releasing hormone auto-immune rats did respond. Castrated and entire males were reported not to respond to

Table 2. Binding of trenbolone to various receptors*

\begin{tabular}{|c|c|c|c|c|}
\hline Receptor & $\begin{array}{l}\text { Source of } \\
\text { receptor }\end{array}$ & $\begin{array}{c}\text { Period of } \\
\text { incubation at } \\
0^{\circ}(\mathrm{h})\end{array}$ & $\begin{array}{l}\text { Binding } \\
\text { relative to } \\
\text { reference } \\
\text { hormone }\end{array}$ & $\begin{array}{l}\text { Reference } \\
\text { hormone }\end{array}$ \\
\hline Oestrogen & $\begin{array}{l}\text { Immature mouse } \\
\text { uteri }\end{array}$ & 2 & 0.1 & Oestradiol \\
\hline Progestin & $\begin{array}{l}\text { Oestradiol-primed } \\
\text { rabbit uteri }\end{array}$ & $\begin{array}{r}2 \\
24\end{array}$ & $\begin{array}{l}75 \\
15\end{array}$ & Progesterone \\
\hline Androgen & $\begin{array}{l}\text { Castrated rat } \\
\text { prostate glands }\end{array}$ & 0.5 & $\begin{array}{l}250 \\
190\end{array}$ & Testosterone \\
\hline Glucocorticoid & $\begin{array}{l}\text { Adrenalectomized } \\
\text { rat thymusses }\end{array}$ & $\begin{array}{r}1 \\
24\end{array}$ & $\begin{array}{l}9 \\
2 \cdot 5\end{array}$ & Corticosterone \\
\hline
\end{tabular}

-After Raynaud et al. (1981). 
trenbolone acetate, however, in this laboratory we have observed small responses to trenbolone acetate in entire male rats (P. J. Buttery, unpublished observations). These experiments do, however, clearly indicate the need that any explanation of the mode of action of trenbolone must account for the sexual dimorphism seen in the growth response of treated animals.

Sinnett-Smith et al. (1983a,b) have shown that zeranol, a compound with oestrogenic properties, does not stimulate muscle protein synthesis in sheep showing an increased growth rate. All evidence indicates that it reduces fractional synthetic rate. It has been suggested that oestrogens stimulate circulatory $\mathrm{GH}$ concentrations and that this accounts, in part, for their growth stimulation (Heitzman, 198I). If this were the case, surely muscle protein synthesis would be stimulated. One very interesting observation is that trenbolone apparently increases circulatory oestradiol- $7 \beta$ concentration in sheep (see Table 3 ). Although the specificity of the assay used can be questioned there are good reasons to believe that this result is real. Trenbolone and zeranol have similar effects on protein turnover in sheep muscle (Table 3). Is it possible that some of the action of trenbolone is associated with an oestrogenic response? However, before jumping to conclusions it should be remembered that Heitzman et al. (I98I) studied the interaction between oestrogens (hexoestrol or oestradiol) and trenbolone on the growth rate of steers. Their conclusion was that the effects were independent and additive. However, Heitzman (198I) does suggest that there is evidence which points to similarities in the mode of action of androgens and oestrogens.

\section{Conclusions}

There is unlikely to be one hormone which is clearly responsible for protein deposition and all muscles may not behave identically. Growth (protein deposition)

Table 3. The effect of trenbolone acetate $(T B A)$ or zeranol $(Z)$ on muscle protein synthetic rates, muscle cathepsin $D$ activity and plasma oestradiol concentration in entire female lambs

(Mean values; no. of lambs in parentheses)

\begin{tabular}{|c|c|c|c|c|c|c|c|}
\hline & & & & & Significa & nce of co & nparison \\
\hline & Control & TBA & Zeranol & SED & $\begin{array}{l}\text { Control } \\
\text { v. TBA }\end{array}$ & $\begin{array}{l}\text { Control } \\
\text { v. } Z\end{array}$ & $\begin{array}{l}\text { TBA } \\
\text { ข. } Z\end{array}$ \\
\hline $\begin{array}{l}\text { Muscle fractional } \\
\text { synthetic rate (/d) } \\
\text { Cathepsin D activity } \\
\text { (units) }\end{array}$ & $0.060(5)$ & $0.039(6)$ & $0.041(5)$ & 0.010 & $P<0.10$ & NS & NS \\
\hline $\begin{array}{l}\text { Free } \\
\text { Total }\end{array}$ & $\begin{array}{r}3.79(5) \\
15.05(5)\end{array}$ & $\begin{array}{r}2.06(4) \\
14.02(5)\end{array}$ & $\begin{array}{r}2.00(3) \\
16.00(6)\end{array}$ & $\begin{array}{l}0.70 \\
1 \cdot 74\end{array}$ & $\begin{array}{c}P<0.05 \\
\text { NS }\end{array}$ & $\begin{array}{c}P<0.05 \\
\text { NS }\end{array}$ & $\begin{array}{l}\text { NS } \\
\text { NS }\end{array}$ \\
\hline$(\mathrm{ng} / \mathrm{l})$ & II $26(5)$ & $26 \cdot 16(5)$ & $12 \cdot 5^{6}(5)$ & $4 \cdot 13$ & $P<0.01$ & NS & $P<0.02$ \\
\hline
\end{tabular}


is more likely to be a response to the hormonal balance favouring anabolism, rather than catabolism. Although only referred to briefly here, it is important that when considering protein deposition, attention must not be confined to proteinaceous tissues. The partition between amino acids and carbohydrates (the influence of glucagon is of importance here) obviously has a significant role to play. Bone growth may also be important if the length of the bones is increased (e.g. by the action of somatomedins), then the muscles which move the bones must be longer and most likely bigger.

The author wishes to acknowledge the helpful discussion with Dr P. A. Sinnett-Smith during the preparation of this review and the Agricultural Research Council for financial support.

\section{REFERENCES}

Anderson, N. C. \& Lieberman, S. (1980). Endocrinology 106, I3.

Ashton, K. (1981). In Proceedings of a Colloquium on Somatomedins, p. 35 [G. S. G. Spender, editor]. Bristol: Somatomedin Club.

Berzins, R. \& Manns, J. G. (1979). F. Dairy Sci. 62, 1739.

Beznak, M. (1982). Can. F. Biochem. Physiol. 40, 1647.

Brockman, R. P., Bergman, E. N., Joo, P. K. \& Manns, J. C. (1975). Am. J. Physiol. 229, 1344.

Brown, J. G., Bates, P. C., Holliday, M. A. \& Millward, D. J. (1981). Biochem. F. 194, 771.

Burgess, T. D. \& Lamming, G. E. (1960). Anim. Prod. 2, 93.

Burroughs, W., Cheng, E., Raun, A., Culbertson, C. C. \& Kline, E. A. (1958). F. Anim. Sci. 17, 1163.

Buttery, P. J., Vernon, B. G. \& Pearson, J. T. (1978). Proc. Nutr. Soc. 37, 311.

Carroll, F. D., Powers, S. B. \& Clegg, M. T. (1963). F. Anim. Sci. 22, roog.

Carter, W. J., Benjamin, W. S. W. \& Faas, F. H. (1981). Biochem. F. 194, 685.

Carter, W. J., Benjamin, W. S. W. \& Faas, F. H. (I982). Biochem. F. 204, 69.

Coates, C. L., Burwell, R. G., Buttery, P. J., Walker, G. \& Woodward, P. (1977). Ann. rheum. Dis. 36, 50 .

Coward, B. J. \& Buttery, P. J. (1980). F. Agric. Sci. 98, 307.

Cox, M. P., Dalal, S. S. \& Heard, C. R. C. (1981). Proc. Nutr. Soc. 40, 39A.

Dahlberg, E. (1982). Biochim. biophys. Acta 717,65.

De Martino, G. N. \& Goldberg, A. L. (1978). Proc. natn. Acad. Sci. USA 75, 1369.

Dionne, F. T., Lessage, R. L., Dube, J. Y. \& Tremblay, P. L. (1979). J. Steroid Biochem. I1, 1073 .

Donaldson, I. A., Hart, I. C. \& Heitzman, R. J. ( 1981 ). Res. Vet. Sci. 30, 7.

Dumelow, N. W., Pearson, J. T., Essex, C. P. \& Buttery, P. J. (I982). Proc. Nutr. Soc. 41, 57A.

Flaim, I. E., Li, J. B. \& Jefferson, L. S. (1979). Am. Y. Physiol. 237, E231.

Fuller, M. F., Weekes, T. E. C., Cadenhead, A. \& Bruce, J. B. (1977). Br. F. Nutr. 38, 489.

Galbraith, H. \& Topps, J. H. (1981). Nutr. Abstr. Rev. 51 , 521 .

Giordino, G., Van Wyk, J. J. \& Minuto, F. (1979). Somatomedins and Growth. London: Academic Press.

Goldberg, A. L., Tischler, M., De Martino, G. N. \& Griffin, G. (1980). Fedn Proc. Fedn Am. Socs exp. Biol. 39, $3 \mathrm{I}$.

Gregory, N. G., Lovell, R., Wood, J. D. \& Lister, D. (1977). 7. Agric. Sci. 89, 407.

Hart, I. C. (1981). In Hormones and Metabolism in Ruminants, p. 47 [J. M. Forbes and M. A. Lomax, editors]. London: Agricultural Research Council.

Heitzman, R. J. (1981). In Hormones and Metabolism in Ruminants, p. 129 [J. M. Forbes and M. A. Lomax, editors]. London: Agricultural Research Council.

Heitzman, R. J., Gibbons, F. N., Little, W. \& Harrison, L. P. (1981). Anim. Prod. 32, 219. 
Kahn, C. R., Baird, K. L., Flier, J. S., Crunfeld, C., Harman, J. T., Harrison, L. C., Karlsson, F. A., Kusuga, M., King, G. L., Lang, V. C., Podskalny, J. M. \& Van Öbberghen, O. (198r). Recent Prog. Horm. Res. 37, 477.

Kochakin, C. D. (1975). Pharm. Therap. 1, 149.

Kostyo, J. L. \& Nutting, D. F. (1973). Horm. Metab. Res. 5, 167.

Lange, W. \& Lindermann, E. (1972). Arch. Tiers. $15,171$.

Lewis, S. E. M. \& Goldspink, D. F. (1982). Biochem. Soc. Trans. 10, I 70.

Lewis, V. J., Singh, R. N. P., Tutwiter, G. F., Sigel, M. B., Van der Laan, E. F. \& Van der Laan, W. P. ( 1980$)$. Recent Prog. Horm. Res. 36, 477.

Livingston, J. N., Purvis, B. J. \& Lockwood, D. H. (1978). Nature, Lond. 273, 394.

Longcope, C., Pratt, J. H., Schneider, S. H. \& Fineberg, S. E. (1978). F. clin. Endocr. Metab. 46, 146.

Lund-Larsen, T. R., Sundby, A., Kruse, V. \& Velle, W. (1977). F. Anim. Sci. 44, 189.

MacDonald, D. C., Madden, J. D., Brenner, P. F., Wilson, J. D. \& Siiteri, P. K. (1979). f. clin. Endocr. Metab. 49, 905.

Machlin, L. J. (1972). F. Anim. Sci. 35, 794 .

Manns, J. G. (1972). Can. F. Physiol. Pharmacol. 50, 554.

Mayer, M. \& Rosen, F. (1975). Am. F. Physiol. 229, I381.

Millward, D. J., Garlick, P. J., Nnanyelugo, D. O. \& Waterlow, J. C. (1976). Biochem. 7. I 56, I 85 .

Momany, F. A., Bowers, C. Y., Reynolds, G. A., Chang, D., Hong, A. \& Newlander, K. (198I). Endocrinology 108,31 .

Odedra, B. R., Dalal, S. S. \& Millward, D. J. (1982). Biochem. J. 202, 363.

Odedra, B. R. \& Millward, D. J. (1982). Biochem. J. 204, 663.

Patel, Y. C., Zingg, H. H., Fitzpatrick, D. \& Snkank, C. B. (1981). In Gut Hormones, 2nd ed., [S. R. Bloom and J. M. Polak, editors]. Edinburgh: Churchill-Livingstone.

Purchas, R. W. (1973). Aust. 7. agric. Res. 26, 477.

Purchas, R. W., Barton, R. A. \& Kirton, A. H. (1980). Aust. F. agric. Res. 3 I, 22 I.

Purchas, R. W., Pearson, A. M., Hafs, H. D. \& Tucker, H. A. (1971). F. Anim. Sci. 33, 836.

Raben, M. S. (1973). In Methods in Investigative and Diagnostic Endocrinology, p. 26I [S. A. Benson and R. S. Yalow, editors]. Amsterdam: North Holland.

Rannels, S. R. \& Jefferson, L. S. (1980). Am. F. Physiol. 238, E564.

Rannels, S. R., Rannels, D. E., Pegg, A. E. \& Jefferson, L. S. (1978). Am. J. Physiol. 235, Er 34.

Raynaud, J. P., Ojasoo, T. \& Labrie, F. (I98I). In Mechanisms of Steroid Action, p. I45 [G. P. Lewis and M. Ginsbury, editors]. London: Macmillan.

Rodway, R. G. \& Galbraith, H. (1979). Horm. Metab. Res. I I, 489 .

Sakata, T., Hikosaka, K., Shiromura, Y. \& Tamate, H. (1980). Br. F. Nutr. 44, 325.

Santidrian, S., Moregra, M. N., Munro, H. N. \& Young, V. R. (1981). Metab. Clin. Exp. 30, 798.

Schanbacker, B. D. (1982). Am. F. Physiol. 242, E205.

Schofield, J. C. (1981). Proc. Nutr. Soc. 40, $3^{6} 5$.

Shoji, S. \& Pennington, R. J. T. (1977). Endocrinology 6, I 59.

Sinnett-Smith, P. A., Dumelow, N. W. \& Buttery, P. J. (I983a). Proc. Nutr. Soc. 42, 58A.

Sinnett-Smith, P. A., Dumelow, N. W. \& Buttery, P. J. (1983b). Br. F. Nutr. (In the Press.)

Snochowski, M., Dahlberg, E. \& Gustaffsson, J. A. ( I 980). Eur. F. Biochem. I 1 1, 603.

Snochowski, M., Lundstrom, K., Dahlberg, E., Petersson, H. \& Edquist, E. (I98 r). F. Anim. Sci. 53,8 o.

Spencer, G. S. (1981a). In Hormones and Metabolism in Ruminants, p. 80 [J. M. Forbes and M. A. Lomax, editors]. London: Agricultural Research Council.

Spencer, G. S. (1981b). Proceedings of a Colloquium on Somatomedins. Bristol: Somatomedin Club.

Stephenson, R. G. A., Ngongoni, N. T., Robinson, J. J., Atkinson, T. \& Chesworth, J. M. (r983). Proc. Nutr. Soc. 42, 37A

Sumner, R. \& Weekes, T. E. C. (1983). Proc. Nutr. Soc. 42, 39 A.

Thomas, K. M. \& Rodway, R. G. (198I). Acta Endocrinol. 97 (suppl. 243), 460.

Thomas, K. M. \& Rodway, R. G. (1983). Proc. Nutr. Soc. 41, 43A.

Tomas, F. M., Munro, H. N. \& Young, V. R. (1979). Biochem. F. I 78, 139. 
Toong, A., Perry, B. N., Lopez, A. \& Ventanas, J. (1981). Proc. Nutr. Soc. 40, 99 A.

Trenkle, A. (1977). Growth 4I, 24 I.

Trenkle, A. \& Topel, D. G. (1978). F. Anim. Sci. 46, 1604.

Van den Brande, J. L., Van Buul-Offers, S. C., DuCaju, M. V. L., Price, D. A., Wilt, J. M. \& Bongers-Schokking, O. (1979). In Somatomedins and Growth, p. 255 [G. Giordano, J. J. Van Wyk and F. Minuto, editors]. London: Academic Press.

Vernon, B. G. \& Buttery, P. J. (1978a). Anim. Prod. 26, I.

Vernon, B. G. \& Buttery, P. J. (1978b). Br. J. Nutr. 40, 563 .

Vernon, B. G. \& Buttery, P. J. (1980). Proc. Nutr. Soc. 40, 1 3 A.

Wagner, J. F. \& Veenhuizen, E. L. (1978). F. Anim. Sci. 47 (suppl. 1), 397 (abstr).

Waterlow, J. C. \& Stephen, J. M. L. (1968). Clin. Sci. 35, 287.

Weekes, T. E. C. \& Godden, P. M. M. (1981). In Hormones and Metabolism in Ruminants, p. 99 [J. M. Forbes and M. A. Lomax, editors]. London: Academic Press.

Wilbur, R. P., Egger, R. G. \& Linkenheimer, W. H. (1967). Fedn Proc. Fedn Am. Socs exp. Biol. 26, 425 .

Young, V. R. (1980). In Protein Deposition in Animals, p. 167 [P. J. Buttery and D. B. Lindsay, editors]. London: Butterworths. 